$J J M L L$

\title{
Translator-oriented Translation Criticism: The Case of Roger Allen's Translation of Khan al-Khalili
}

\author{
Mohammed Al-Batineh * \\ Department of Translation, Yarmouk University, Jordan \\ Department of English, Sultan Qaboos University, Oman \\ Rokaia Alsmadi \\ Department of Translation, Yarmouk University, Jordan
}

Received on: 30-11-2020

Accepted on: 30-5-2021

\begin{abstract}
Situated within translator studies, the present paper adopts Berman's (1995) translator-oriented approach to translation criticism to analyze the English translation of Naguib Mahfouz's Khan al-Khalili by Roger Allen. The paper analyzes two sets of data related not only to the translated novel but also to the translator as a cultural agent. The first set includes a collection of paratexts produced by Allen, including articles, interviews, introductions, and afterwords. The second set of data includes the Arabic and English versions of Khan al-Khalili. The paratextual data was analyzed to reveal Allen's translating position, horizon, and project, while the second set was analyzed to reveal the extent to which Allen's project is aligned with his translation of Khan al-Khalili. The result of the analysis revealed that Allen's project is aligned with his translation, which produced a foreignized version of the novel that introduces the reader to Arab culture.
\end{abstract}

Keywords: Translation Criticism, Translator Studies, Roger Allen, Arabic Literature in Translation, Naguib Mahfouz.

\section{Introduction}

In his seminal work, The Name and Nature of Translation Studies, Holmes (1979, 182) lists translation criticism as a branch of applied translation studies concerned with the evaluation of translated text. Translation criticism, or translation evaluation, is a controversial topic in translation studies. It has mostly been approached from a product-oriented point of view, focusing either on the target text or on the relation between the original text and its translation. Early models of translation criticism were developed by scholars in the linguistic school, such as Catford (1965) and Nida (1964), who focused on individual lexical items and their translation in the target language. The linguistic approach to translation criticism adopted equivalence and faithfulness as metrics for evaluating the success or the failure of a translation, ignoring the function of the translated text in the target culture and language.

Later, functionalist translation scholars (Vermeer 2000; Reiss 1976; Nord 1997; Reiss and Vermeer 1989) challenged the long-held view of translation as simply replacing words with their equivalents and

() 2021 JJMLL Publishers/Yarmouk University. All Rights Reserved,

${ }^{*}$ Doi: https://doi.org/ 10.47012/jjmll.13.3.11

*Corresponding Author: M_bataineh@yu.edu.jo 
emphasized the importance of considering the function of the target text in its new environment. According to the functionalist approach, a successful translation should adapt the source text to the norms of the target language and culture (Reiss and Vermeer 1989). That is, translation quality is judged based on its success in reflecting the function of the text in its new environment. The functionalist approach shifts the focus from source-oriented to target-oriented translation criticism. Translation criticism has become more concerned with the function of the target text (TT) and has departed from any linguistic constraints imposed by the source text (ST).

Until recently, translation critics have mainly focused on either the source text's translation process or on the target text's semantic, syntactic, and stylistic features. Little attention has been paid to the agent who creates the target text: the translator. The emergence of the "translator turn" (Robinson 1991) and "translator studies" (Chesterman 2009) have added new dimensions to translation criticism. In this regard, Berman (1995) criticized previous models of translation criticism for not considering translators. He argued for analyzing the translated text as the main element of a translational act; subsequently, scholars should research the "translating subject" or the translator when evaluating a specific literary text's translation. He proposes a model for translation criticism that centers source texts, their translations, translators, and paratextual materials produced by said translators. The concept of paratexts, as used by Genette (1997), refers to the written materials accompanying and presenting a text, such as prefaces, postfixes, titles, dedications, and afterwords (1). Translational paratexts are significant because they offer insights into the presentation and reception of translated texts within the target culture. Paratexts also provide valuable information related to a translator's education, cultural background, and translation methods.

The present study applies Berman's (1995) approach to translation criticism to evaluate Roger Allen's translation of Khan al-Khalili written by Arab Nobel laureate Naguib Mahfouz. Previous studies that tackled Arabic-English translation criticism have been text-oriented, focusing on the source text and its realization in the target language (See Al-Qinai, 2000; Alwafai, 2015; Behtash \& Moghadam, 2017; Almutairi, 2018). In this paper, the analysis of Allen's translation goes beyond the source and target texts and critically analyzes paratextual material, interviews, and articles produced by Roger Allen. The following section provides a general overview of the related literature.

\section{Arabic Translation Criticism}

Previous translation criticism studies have focused on the linguistic transfer of texts from one language into another, judging the translation quality based on the level of divergence from the source text. Researchers mostly focused on the translated text with an emphasis on either the translation strategies adopted by the translator or on linguistic, cultural, or syntactic issues in the translation. This line of research has attracted the attention of several translation researchers, including Alwafi (2015), AlAmayreh (2019), El-Zawawy (2019) and Sayaheen et al. (2019).

For instance, Alwafi (2015) analyzes two Arabic translations of The Old Man and the Sea by Ernest Hemingway (1952). In her analysis, Alwafi delves into the problems and strategies of literary translation into Arabic. She then offers potential best practices that would enhance current strategies in English- 
Arabic literary translation. Alwafi (2016) adopts Baker's (1992) theory of equivalence, which provides a tool for researchers to analyze translations at the word level. In her analysis, Alwafi's (2016) data are descriptive and qualitative. She provides examples of lexical items that were successfully and unsuccessfully translated into Arabic. Based on the translation issues in the Arabic version of the novel, Alwafi provides suggestions for translation strategies that would help literary translators avoid such potential missteps.

Similarly, Al-Amayreh (2019) compares two Arabic translations of Hamlet by evaluating excerpts taken from both translations and investigating the strategies used by translators when rendering the text into Arabic. In her analysis, Al-Amayreh (2019) takes the source text as a point of departure for her evaluation. She argues that the closer the translated text is to the source text, the more accurate and faithful the translation. She points out that a "faithful" translation allows target text readers to "imagine the same picture the source text intends to convey" (Al-Amayreh 2019, 240). Al-Amayreh's (2019) analysis of Hamlet is purely linguistic and focuses mainly on the source text's lexical items and their equivalent renditions in the target text. Al-Amayreh (2019) reports that two main translation strategies were used by the translators: addition and omission. She concludes that both translations are successful since they produce an equivalent, "faithful" translation of the source literary work.

Adopting a text-oriented approach, El-Zawawy (2019) investigates the syntactic, semantic, and figurative challenges faced by the English translators, Trevor Le Gassick and Humphrey Davies, of Midaq Alley (2011). The researcher also discusses translation strategies adopted by Le Gassick and Davies to solve said issues. El-Zawawy's (2019) approach focuses on how the translators dealt with the syntactic structure of the source novel when translating it into English. Similarly, Sayaheen et al. (2019) conduct a textual analysis of two Arabic translations of Alice's Adventures in Wonderland, one by Ameera Kiwan (2003) and the other by Shakeer Naser Ad-Deen (2012). They focus on the issue of translating children's literature from English into Arabic. The researchers attempt to reveal whether the two translators adopted domestication or foreignization translation methods in their different versions. They found that both methods were employed in both translations. However, Kiwan's (2003) version is more foreignized compared to Naser Ad-Deen's (2012).

Most of the studies evaluating Arabic literary translation have discussed the linguistic and cultural issues present when translating literary works from or into Arabic. However, translator-oriented translation criticism has rarely been considered within the discipline. This area of investigation has attracted some scholarly attention in other languages. In the Persian context, Moghadas (2014) used Berman's approach to evaluate the Persian translation of Austen's Pride and Prejudice, which was translated by Reza Rezaei. Moghadas (2014) found that the translator's background and style played a significant role in shaping the final translation. Moghadas (2014) argues that adopting Berman's (1995) model of translation criticism helps researchers uncover how translators' personal backgrounds affect their rendering of literary works into the target languages. This, as Moghadas (2014) points out, has significantly contributed to the understanding of why certain items are rendered in a specific way. 
The present study aims to investigate the impact of Roger Allen's position, project, and horizon on his translation of Mahfouz's Khan al-Khalili (2008) by applying Berman's (1995) approach to translation criticism. The study evaluates Roger Allen's translation of Khan al-Khalili to reveal the extent to which the translator successfully converts the cultural, stylistic, and linguistic aspects of Mahfouz's novel into English in light of the translator's position, horizon and project.

\section{Berman's Model of Translation Criticism}

Berman's approach to translation criticism is a four-stage method (Massardier-Kennedy 2009, ix). First, the translation critic must read and reread the translated text as an independent piece without referring to the source text. Conversely, the second stage involves reading the source text without referring to the target. The reading of the source and target texts serves to locate problematic issues in both versions. The third stage involves analyzing paratextual material (prefaces, afterwords, glossaries, interviews, and articles) written by the translator to reveal the translator's approach and nonlinguistic aspects that could impact the translation. This third stage is meant to determine the translator's translating position, translating project, and translating horizon (explained in more detail in the following sections). The last stage includes the confrontation, which is the analysis of problematic zones in the source text and its translation in light of the translator's position, horizon, and project.

\subsection{Translation Reading and Rereading}

According to Berman's approach (1995), the translation critic should start by reading the target text as an original text. During this reading, the critic sets the original text aside and examines the strength, cohesion, and coherence in the target text. In other words, the critic tests whether the translated text stands on its own in the receptor language and conforms to its written norms (Berman 1995, 50). This first reading frees the critic from committing unconscious comparisons with the source text and potentially failing to consider the translation as a literary text (Massardier-Kennedy 2009, ix). The critic reads the translated text to discover problematic "textual zones", which could be weak style, inconsistent rhythm, ineffective forms, or terms that do not belong to the target language system (Berman 1995, 50). Ultimately, this stage serves to locate how the problematic "textual zones", which were discovered in the translation, were originally written in the source language.

\subsection{The Reading of the Original}

When reading the original work, a "textual pre-analysis" serves to locate any stylistic and linguistic peculiarities in the original text (Berman 1995, 51) and to select "pertinent and significant stylistic examples" from the original work (Berman 1995, 54). This may include distinctive phrasing and linking clauses as well as certain uses of adjectives, adverbs, verb tenses, and prepositions. The reading of the original helps the critic find, what Berman (1995) calls, "signifying zones" in the source text, which are "where a literary work reaches its own purpose" (54). Stylistic peculiarities, problematic "textual zones," and "signifying zones" are the basis for the textual confrontation, which cannot be executed without 
understanding the logic of the translated work. Such logic is only revealed by analyzing and searching the “translating subject" or the "translator" (Berman 1995, 57).

\subsection{Search for the Translator}

Berman's (1995) approach contributes to current and previous translation criticism by focusing on the translator as a key factor that can impact how the target text is shaped and produced. Berman argues that the critic should familiarize him/herself with the life, cultural background, and works of the translator. Most importantly, according to Berman's model, the critic should know if translators have written articles, studies, dissertations, or monographs about what they have translated and if they have written about their practice as translators, thus sharing the principles that guide them through the work of translation (Berman 1995, 58). The critic can collect all of this data by investigating a translator's paratexts and interviews. Berman's model provides a defined path for uncovering a translator's impact by analyzing three main types of translator-specific information: his/her translating position, translation project, and translating horizon. Because these concepts are directly related to the translator, they are revealed through a deep analysis of paratextual materials. These three concepts are discussed in more detail in the sections below.

\subsubsection{The Translating Position}

The translating position is a translator's perception and conception of the translation activity (Berman 1995, 58). The translating position could also reveal the translator's language position, which in turn demonstrates the translators' relation to the source or target language. This relation could impose certain translation strategies on the translator, such as foreignization, which adds a "prestigious" flavor to the text when translating from a dominant language into a dominated one. Berman (1995) argues that the translating position may not be explicit (59). However, we can guess translating position through an indepth exploration of textual materials produced by translators about their translations such as paratexts or interviews where they discuss their craft (Berman 1995, 59).

\subsubsection{The Translation Project}

The translation project defines how the translator realizes the literary transfer, the mode of translation, and the chosen style of translation adopted by the translator (Berman 1995, 60). The critic's task is to see if the final product of translation stands as promised by the translator in the paratextual material accompanying his/her translation; otherwise, any defects in the translation are the fault of the project or a specific part of the project.

\subsubsection{The Horizon of the Translator}

The horizon of the translator, as Berman (1995) defines it, is "the set of linguistic, literary, cultural, and historical parameters that determine the ways of feeling, acting, and thinking of the translator" (63). For Berman (1995), the horizon can also be the "horizon of expectations," which could, in turn, have an impact on the way the translation is produced and packaged (63). The relation between the target 
readership and language of the foreign text is also considered part of the horizon, which could impact how the target text is written. Berman (1995) indicates that the horizon further includes the state of and the discussion of translation and translators in general. The horizon can be the position of translated literature within the literary polysystem of the receiving environment, place, and time.

It is worth mentioning that the relation between the three above stages is not linear; rather, the three stages could be carried out in different arrangements.

\subsubsection{Analyzing the Translation: The Confrontation}

In this stage of data analysis, the critic's task is to see the extent to which the translation follows the translation project through a comparative analysis of the original, the translation, and modes of implementation for the project. According to Berman (1995), analyzing the translation is a critical phase for criticizing the translation, and it must be conducted on four levels of confrontation:

(1) A confrontation between the selected elements and passages in the original and the rendering of the elements and selected textual zones in the translation (Berman 1995, 68).

(2) A confrontation between the selected textual zones spotted in the translation and the corresponding textual zones of the original (Berman 1995, 69).

(3) A confrontation between the translation and its project, which reveals the "how" of its realization.

(4) When confrontations reveal any discordance between the project and its realization, the confrontation must determine the nature, form, and cause of the discordance.

Berman (1995) argues that any gap between the project and its translation results in a defect in the translation. He also points out that the critic, when writing his/her criticism on a specific translation, should keep technical terms to a minimum and should explicate as much as possible. He adds that the critic should avoid including too much of the original language in his/her analysis because the critic must assume that the reader of the analysis is the reader of the translation. After all, he/she could not read the original work in the original language (Berman 1995, 70).

\section{Methodology}

\subsection{Data Collection}

This study relies on two sets of data. The first set includes Naguib Mahfouz's novel Khan al-Khalili (1986) and its English translation by Roger Allen (2008). The second set includes reviews, articles, books, and paratexts produced by Allen talking about him as a translator and about his translations (See Table 1). 
Translator-oriented Translation Criticism: The Case of Roger Allen's

Translation of Khan al-Khalili

Table 1: Paratextual Material Produced by Roger Allen.

\begin{tabular}{ll}
\hline \multicolumn{1}{c}{ Types of Paratexts } & \multicolumn{1}{c}{ Title } \\
\hline Article & "Arabic Literature and the Nobel Prize" (Allen 1988) \\
Article & "Translating Arabic Literature" (Allen 2003) \\
Article & "Rewriting Literary History: The Case of the Arabic Novel" (Allen 2007) \\
Article & "Translating Arabic Fiction" (Allen 2015) \\
Article & "The Happy Traitor: Tales of Translation" (Allen 2010) \\
Book & The Arabic Novel, An Historical and Critical Introduction (Allen 1995) \\
Book & Introduction to Arabic Literature (Allen 2000) \\
Afterword & Khan al-Khalili (Allen 2008) \\
Interview & Interview with Roger Allen (Alkhawaja 2014) \\
Interview & Pioneer Translator Roger Allen on a Text He's Been Working with for the \\
& Last 50 Years (ArabLit 2015) \\
Lecture & Arabic and Translation: A lecture by Dr. Roger Allen (American University \\
& of Beirut 2017)
\end{tabular}

\subsection{Data Analysis}

The data analysis included two stages. The first stage entails critically reading Allen's paratexts to reveal his translating position, translating project, and translating horizon. The paratexts were analyzed by the researchers and tagged for four types of information: Allen's life and education, horizon, position, and project. The second stage, the confrontation, includes an analysis of the Arabic source novel and its translation through the lens of Allen's translation project. The textual analysis of the source and target texts started with reading the target text as a stand-alone piece to spot problematic "textual zones" where the translator succeeded or failed. This stage was then followed by a close reading of the original text to locate any stylistic and linguistic peculiarities (Berman 1995, 51) and to select "signifying zones" in the source text. During this stage, the researchers also traced the context of the problematic "textual zones" from the translation. The third stage of data analysis involved textual confrontation. In this stage, the researchers relied on the stylistic peculiarities, the problematic "textual zones," and the "signifying zones" that were spotted in the first two stages. The researchers categorized the peculiarities and zones into four categories depending on their themes, including food and clothing lexical items, religious expressions, Arabic characters' titles, and culture-based conversations. The selected examples were then analyzed in light of Allen's project, which was based on his paratextual material.

\section{Findings and Discussion}

Due to space limitations, this section discusses only fifteen excerpts taken from the source text. The included examples are intended to provide a sense of the characteristics of the Arabic text and the problematic textual zones included in the source text. 


\subsection{In Search of Roger Allen}

Roger Allen is a translator and a professor of Arabic literature. He has lived in several Arab countries including Egypt and Sudan (Allen 2015). Allen's Ph.D. dissertation was his first encounter with Arabic literature from an academic perspective; it was a study and English translation of Muhammad alMuwaylihi's Hadith 'Isa ibn Hisham ('Isa Ibn Hisham's Tale). His dissertation was later published in book form as A Period of Time (1992). Allen's interest in modern Arabic fiction began when he translated Mahfouz's God's World: An Anthology of Short Stories (1973) in collaboration with Akef Abadir. Allen has also translated Jabra Ibrahim Jabra's The Ship (1985) and In Search of Walid Masoud (2000), both in collaboration with Adnan Haydar. He has produced successful translations of Yusuf Idris' In the Eye of the Beholder (1978), Abd al-Rahman Munif's Endings (2007), and Mary Telmissany's novel Dunyazad (2000). The latter was listed as the best-translated novel in England of 2000 (Allen 2004). Moroccan works Allen has translated include BenSalim's The Polymath (2009a) and The Theocrat (2009b), and Hanan al-Shaykh's The Locust and the Bird (2009) (World Who's Who 2018).

For much of his life, Allen has been involved in Arabic culture and closely connected with Arab litterateurs. He frequently visited Cairo and the wider Arab world for different cultural and literary conferences and events. For instance, Allen was one of the main participants at the conference for $A l$ Maglis al-A'la li-al-Thaqafa (Supreme Council for Culture). Academically, Allen was involved with several schools and universities in Tunis, Morocco, and other schools in the Arab world as a lecturer and a Ph.D. supervisor (Allen 2004). He has authored and co-authored many books on Arabic language and literature (Allen and Allouche 1986; Allen 1992; 1995; 2000). Of particular interest to this study is that Allen has published many academic articles discussing Mahfouz's works and Modern Arabic literature in general (Allen 2015; 1988; 2010; 2007; 2011).

Allen's involvement in Arabic literature as an author, translator, and professor has given him a unique position as an Arabic-English translator. His attitude toward and perception of translation and translating Arabic literature have been widely expressed in articles, interviews, and paratextual material accompanying his translations.

\subsubsection{Allen's Translating Position}

Allen sees literary translation as a transcultural analysis and interpretation of a text in a source culture. This endeavor needs a highly skilled and knowledgeable translator to convey the linguistic and stylistic peculiarities of the source text into the target language. When it comes to Allen's perception of translation as a profession, he argues that literary translation of Arabic texts "is not a profession in which there are any degrees or standards or rewards" (Halim 2006). He adds that "the rewards for translation are absolutely minimal in any tangible sense", and "everyone has to be doing other things in order to earn living" (Alkhawaja 2014, 85). Translation for Allen is an activity that a translator does in his/her spare time (Allen 2010, 475). However, Allen's pessimistic attitude towards the translation profession has not stopped him from working as an Arabic literary translator. 
Translator-oriented Translation Criticism: The Case of Roger Allen's

Translation of Khan al-Khalili

\subsubsection{The Translation Project}

The translation project is the manner, style, and mode that a translator chooses to complete the work of translation. Allen talks about his project, as a translator, in several interviews and articles (Allen 2010; 2015; ArabLit 2015; Alkhawaja 2014). When discussing his approach or project in translating Arabic literature, Allen always mentions Schleiermacher's (2012) two methods of translating: foreignization and domestication. Allen's preference has been toward the "foreignizing" strategy (Allen 2010). In a recent interview, Allen points out:

In my articles and speeches, I note the dichotomy established by the German philosopher, Schleiermacher, between "domesticating" the original text on the one hand and "foreignizing" the reader of the translated text ...I definitely espouse the latter of the two. (Alkhawaja 2014, 83)

For Allen's project, the purpose of the translation is to confront the reader with a foreign text that is different from texts written in the reader's target language. He does so by borrowing culture-specific terms for his translation. Allen also adds a glossary of the borrowed words at the back of the book (American University of Beirut 2017). In an interview, Allen explains that, when translating Arabic literature, he tries to:

deliberately expose the reader of the translated text to the differences involved in exposure to a foreign language and culture. Among the consequences of that approach are a resort firstly to the use of afterwords at the end of the text rather than any kind of introductory material; and the use of a glossary at the end of the text rather than either inserted translations/explanations or footnotes (Alkhawaja 2014, 82).

Allen adopts this method in his project to make the text look foreign so that the reader remains aware that he/she is reading a translation. In his project of Khan al-Khalili, Allen's translation was mostly foreignized. He used borrowing and literal translation as the two main translation strategies to keep the flavor of the source text (this is explained in more detail in the confrontation section). Like with Allen's other works, the translated version of Mahfouz's novel includes a glossary of the borrowed words used throughout the book. The realization of Allen's project is discussed further in the confrontation section and reveals the extent to which Allen's project is aligned with his translation of Mahfouz's Khan alKhalili.

\subsubsection{The Horizon of the Translator}

As mentioned earlier, the horizon of the translator, as defined by Berman (1995), is "the set of linguistic, literary, cultural, and historical parameters that determine the ways of feeling, acting, and thinking of the translator" (63). It also refers to the horizon that surrounds the production of the translation, which includes the sociopolitical factors that could impact the translation and refers to the horizon of the expectations of the readership.

In his articles and paratexts, Allen discusses three main elements related to the horizon of his translations: readership, publishers, and Arab authors. Allen argues that "Anglophone readerships exhibit by far the lowest interest of Western literary cultures in translations of other cultures' literary production, most notably fiction" (Allen 2015, 164). Similarly, publishers are "minimally interested in the creativity 
Al-Batineh, Alsmadi

of Arab-world writers" (Allen 2015, 165). The vast majority of Arabic titles published in the United States come from a small selection of university presses, primarily the American University in Cairo Press. Allen also points out that Arabic courageous writings that discuss politics, corruption, or sex in the Arab world draw the "attention of Western publishers (and their implied readerships) to these works" (Allen 2009, 12). Such works, Allen indicates, "find a ready readership for what they purport to reveal in the fictional form" (Allen 2009, 12). The interest of Anglophone readers and Western publishers in certain themes has impacted the horizon of translation and, thus, the translation flow of Arabic literary works into English.

As for the horizon of the translator, Allen points out that translators of Arabic literature "have operated, and continue to do so, in a 'discouraging environment"' (Allen 2015, 166). This unsupportive climate is not only shaped by the lack of publishers' interest in publishing Arabic literature in translation but also by the lack of readership beyond the bounds of academia (Allen 2015, 166). This negative horizon, on the other hand, has been formed by Arab authors' immense interest in having their works translated into English. The translation horizon has also been improved by establishing research institutions and university presses for Arabic literature, such as the American University in Cairo in 1927, the American Research Center in Egypt (ARCE) in 1948, and the Center for Arabic Studies Abroad (CASA) (Allen 2004).

\subsection{Reading and Rereading Mahfouz's Novel in English}

The English version of Khan al-Khalili opens with a scene describing a regular afternoon as civil servants finish their work and leave their government offices. It smoothly moves to introduce the protagonist of the novel, Ahmad Akif, a middle-class man who recently moved from Al Sakakini to Khan al-Khalili, escaping the German bombing of his old neighborhood. The story takes place in Khan alKhalili, a traditional neighborhood in Cairo, during World War II. The novel is an important sociohistorical text that not only narrates a story but also documents the social and historical realities of the Egyptian middle-class during the 1940s. The novel can be categorized as an Egyptian social-realistic novel that relies on the narrator to describe events and characters as well as depends on the characters' monologue and dialogue to build the storyline.

Social realism as a trend in Arabic literature appeared in the mid-1940s as an attempt to reflect the life of ordinary people in Arab societies. This literary trend can be narrowly defined as a narrative that reflects the everyday real life of common people including the lower and middle class. Drawing on the notion of social realism as a literary trend, the English version of Khan al-Khalili successfully depicts the life and manners of the middle class, starting from the moment they leave their offices, followed by the tiring commute through busy Cairo, and ending in their modest homes.

The English version of Mahfouz's novel succeeds, in many places, in portraying the traditional busy markets and neighborhoods in Cairo. The excerpt in Example 1 portrays a vivid image of the Khan alKhalili neighborhood: 
Translator-oriented Translation Criticism: The Case of Roger Allen's

Translation of Khan al-Khalili

\begin{tabular}{|l|}
\hline Example 1 \\
\hline The sidewalks of these passageways and the main street itself were \\
crowded with various stalls: watch repairer, calligrapher, tea maker, \\
rug maker, clothes mender, trinket seller, and so on. Here and there \\
cafes were scattered around, but they were no larger than the stalls. \\
..The various craftsmen sat in front of their stalls, patiently and \\
skilfully plying their trade and producing little masterpieces; the \\
ancient quarter still preserved its long-standing reputation as a place \\
where the human hand could make exquisite crafts. (Mahfouz 2008,8)
\end{tabular}

The novel also provides important social and religious context for how Muslim characters celebrate Ramadan. The novel shows that Ramadan is a holy month in the Arab world and demonstrates how middle- and lower-class people prepare for the month. The following excerpt describes in detail the way Egyptian families welcome Ramadan:

\section{Example 2}

In the few days left before Ramadan actually started, the mother busied herself getting the kitchen ready, cleaning pots and pans, and storing away almonds, sugar, onions, and spices... What was best about the month were the long nights and enjoyable visits where conversation would be accompanied by the cracking of nuts and melon seeds... (Mahfouz 2008, 103)

Reading and rereading the English novel, as a stand-alone text without referring to the ST, confirms that the text has been translated from another language and refers to a culture that is different from that of the target reader. For instance, the names of the characters and many culture-specific and Islam-specific terms and expressions were borrowed or translated literally. Honorifics such as Sitt (Mrs.), Sayyid (Mr.), and Hanem (Madame) were consistently borrowed from Arabic. Borrowing was also evident when naming food into the target language, resulting in types of food that do not belong to the target culture system, such as tammiya, ful mudammis, and Kunafa.

A sense of literalness is also noticed in the English version. Literal translation, as used by Allen, produced language and phrasing that are unusual to the target language system. For instance, before opening his shop in the morning, one of the characters says: "O God, Opener, All-Knowing!" (Mahfouz 2008, 103). This phrase is used by Muslims to supplicate Allah by his different names (God, Opener, and All-Knowing) to make a person's day a good one. Another alien saying that is widely used in Arabic culture and considered foreign to the English reader is "whatever's imprinted on the forehead must be visible to the eye," which means "what will be, will be". It was clear from reading the novel twice that Allen used a language of translation to produce a foreignization effect, or what Berman (1999) calls "source language interference", in the English version as Arabic terms, sayings, and expressions were borrowed or literally translated into English.

\subsection{Reading Mahfouz's Novel in Arabic}

By reading and rereading the original, stylistic aspects of Mahfouz's novel can be uncovered and then used to determine his particular types of phrasing, ways of connecting words, and use of adjectives 


\section{Al-Batineh, Alsmadi}

and adverbs. Reading the original as a phase also aims to discover textual zones that are problematic in the translation. After reading the Arabic version of Khan al-Khalili, it was noticed that the novel is a pure social novel written in simple language to be easily understood even by uneducated readers. What distinguishes Mahfouz's writing style is its many detailed descriptions of characters and places in Egypt. Overall, Khan al-Khalili is a realistic novel that talks about Egyptian society in detail, including food, customs, religious places, and celebrations, such as Al-Hysain Mosque, Eid al-Fitr, and Eid al-Adha. The novel also provides background for emotional events common in Egypt during World War II.

Mahfouz's use of culture-specific and Islam-specific terms makes it difficult for Allen to render the source text into English because of the cultural gap between Arabic and English. In the Arabic text, Mahfouz mixes Arabic-Islamic culture with Egyptian social life to produce a unique text that is hard to translate without having in-depth knowledge of Arabic, Islamic, Egyptian culture, and everyday social life. The following Arabic excerpt is an example:

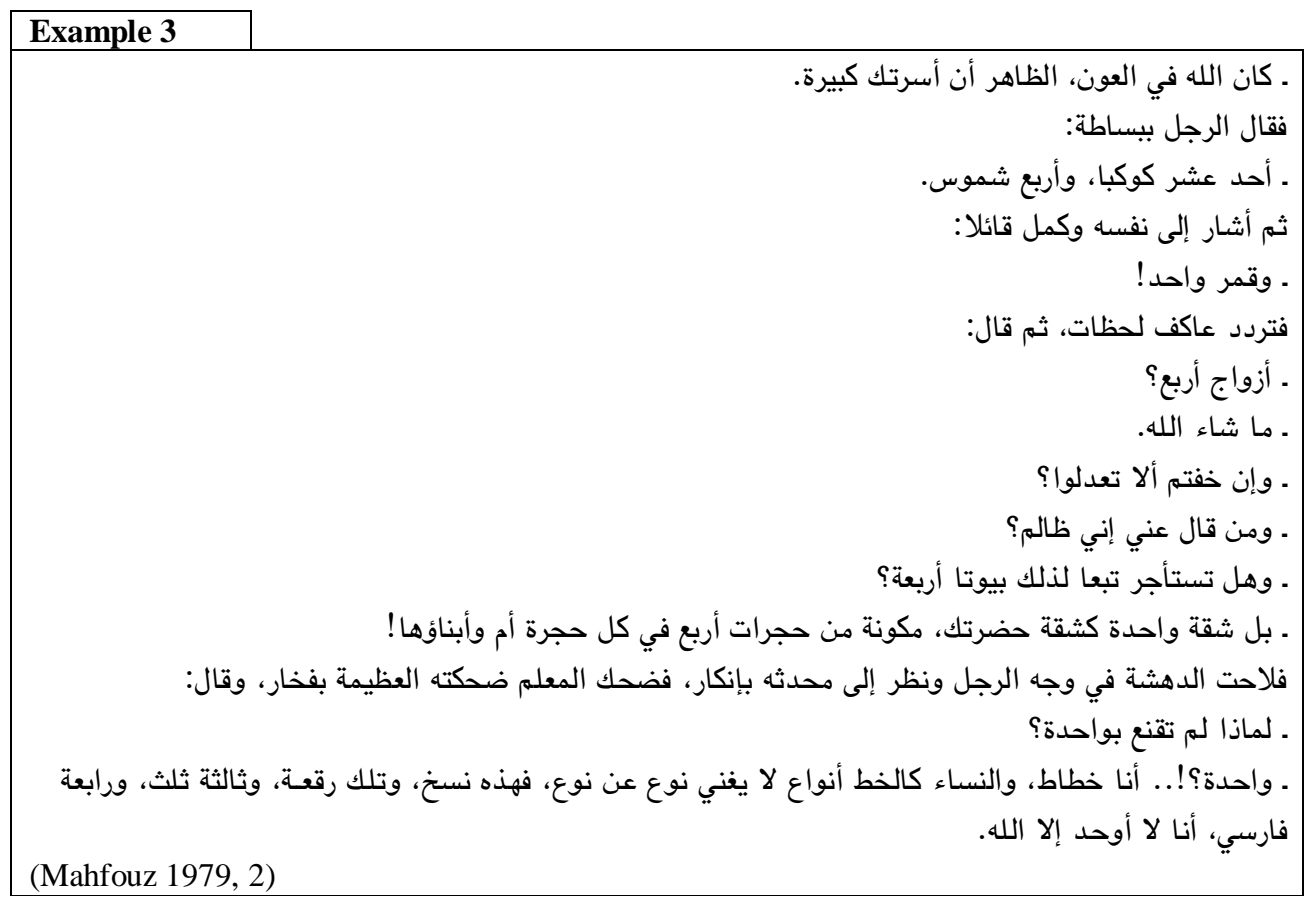

The above conversation contains textual zones with culture-specific and religion-specific references, which are challenging for the translator to render into English. In this example, Ahmed asked Nunu, who is a calligrapher, about his family. Nunu answered that he has eleven planets (sons and daughters), four suns (wives), and one moon (himself). Ahmed was surprised by Nunu's answer and asked him, "Why haven't you been satisfied with just one?" (Mahfouz 1979, 2). Nunu replied that he loves women, and one for him is not enough because each woman has characteristics that make her different from others. In the above conversation, Nunu described women as Arabic calligraphy or fonts (Naskh, Thuluth, Ruq'a, Farsi), indicating that no single woman can supplant the others. He adds that the only thing that is one for him is God (Allah). 
Because the conversation's deeper meaning lies embedded in the text via intertextuality, not on the surface, this passage requires nuance to translate. The conversation refers to a Quranic verse that explains the rules for having more than one wife. Ahmed makes use of this verse to ask Nunu questions and to show his attitude toward polygamy. The concept of polygamy and Arabic font types could be unknown to the target text reader because of the cultural gap between the source text and the target text culture. The intertextuality embedded in Mahfouz's text, the concept of polygamy, and the metaphor of Arabic calligraphy are problematic for the translator when rendering the excerpt into English.

As mentioned earlier, the impact of Islamic culture in Mahfouz's novel is clear. This impact manifested in his use of several Quranic expressions and verses. Like the previous example, this makes the task of the translator more difficult. An example of such a reference includes:

\section{Example 4}

$$
\text { ولا تفلل يدك إلى عنقك ولا تبسطها كل البسط (Mahfouz 1979, 78) }
$$

This Quranic expression means "do not chain your hand to your neck nor open it completely"; the intended meaning is that you must spend your money moderately and wisely (to be neither miserly nor extravagant). Such idioms used by Mahfouz make it harder for Allen to render this Arabic text into English. To translate the phrase, the translator must have extensive knowledge of Islam and the chapter being quotes, as a literal translation would not convey the meaning of the phrase. Another excerpt that has cultural-specific and religion-specific references is the following section:

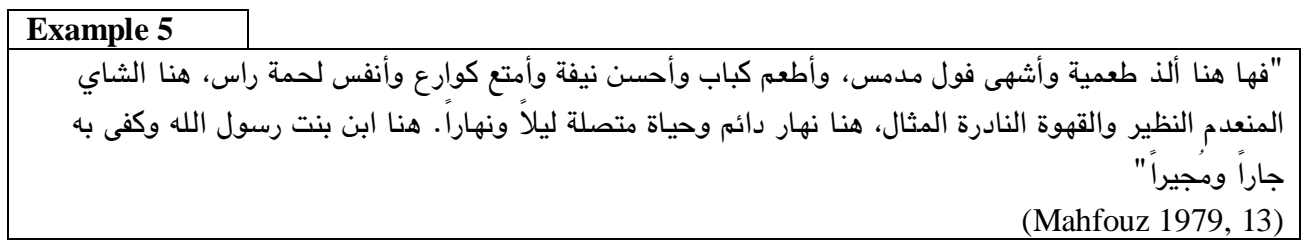

This textual zone lists the traditional foods that people in Khan al-Khalili like and usually eat for breakfast and other meals. Such food includes (كعمية،(falafel), فول مدمس، (fava bean), كباب، (ground meat), كوارع، لحمة راس (trotters), and (sheep's head). The differences between the ST culture and the TT culture create another obstacle for the translator when rendering the above textual zone into English. The example also discusses the people's of Khan al-Khalili belief that the mausoleum of Al-Husayn, the son of the prophet's daughter, protects the neighborhood from everything.

The above textual zones are a few examples of those problematic for the translator. These textual zones and others will be discussed later in more detail by referring to the Arabic and English novels as well as to Allen's project. The following section digs deeper into the life, movements, and statements of Roger Allen. 


\subsection{The Confrontation: Foreignizing Mahfouz's Social Novel}

Mahfouz was among the Arab pioneers who adopted social realism in their literary works. In Khan al-Khalili, Mahfouz tries to reflect Egyptian real life during World War II in the 1940s. This includes conversations between common people in traditional cafés in Cairo as well as other aspects of everyday life. As mentioned earlier, the Arabic version of Mahfouz's Khan al-Khalili is built upon the place's different culture-specific items including Egyptian food, customs, holidays, and clothing. In his translation, Allen not only reflected the source's realistic narrative but also kept the Egyptian foreign flavor in the target text. As revealed in the above translation project section, Allen has always preferred foreignization when rendering Arabic literary works into English (Allen 2010; Alkhawaja 2014; American University of Beirut 2017). In his interviews and paratexts, Allen emphasizes that when executing his translation project, he uses foreignization as a strategy to "deliberately expose the reader of the translated text to the differences involved in exposure to a foreign language and culture" (Allen 2012, 82). To achieve this goal, Allen borrowed many Arabic terms for his English version, and Mahfouz's foreign voice can be heard in the target text, especially when talking about the culture, religion, and food of Egypt.

The following sections build on Berman's (1995) notion of confrontation and analyze selected textual zones to examine how Allen's translation project was realized in his English version of Khan alKhalili. Due to the space limitations, only a few examples are discussed.

\subsubsection{Rendering Items of Food and Clothing into English}

Food items are mostly foreignized by Allen either by borrowing the Arabic terms or by literally translating them into English. In Example 6, one of the characters talks about the good traditional food found in their neighborhood of Khan Al-Kalili. Such food items constitute favorite meals Egyptian people usually eat throughout the day. In the Arabic version, Mahfouz provides a cultural and social record of life in a traditional neighborhood in Cairo through food, which was rendered well into English in Example 6.

\begin{tabular}{|c|c|}
\hline Example 6 & \\
\hline \multicolumn{2}{|c|}{ 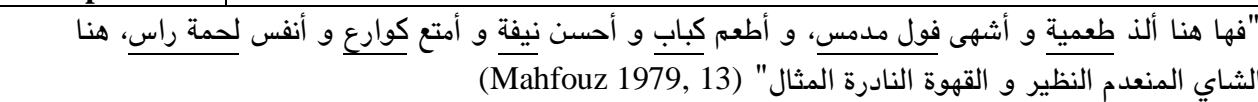 } \\
\hline $\begin{array}{l}\text { "It's not onl } \\
\text { head as well }\end{array}$ & $\begin{array}{l}\text { ful mudammis, but kebab, goat meat, trotters, and sheep's } \\
\text { offee like it anywhere else". (Mahfouz } 2008,14 \text { ) }\end{array}$ \\
\hline
\end{tabular}

Allen successfully executes his translation project by using borrowing to render the authentic cultural food of Egypt; فعمية،(falafel), كول مدمس، (ground meat) become taamiya, ful mudammis ${ }^{l}$, and kebab. Borrowing is a translation strategy that directly translates a lexical item into the TL (Vinay and Darbelnet 1995, 85). Translators usually opt for this strategy because of a gap in the TL lexicon; they also use it to add an element of local color to the target text (Almanna 2016, 57). In his translation, Allen has borrowed many Arabic terms as a way to add an Egyptian flavor to the target text. 
Other food items from Example 6 like كوارع (trotters) and لحمة راس (sheep's head) were translated literally, which further contributes to the foreignness of the translation. By doing so, Allen fulfills his promise of foreignizing the Arabic text in English.

Another essential element of Egyptian culture that was successfully foreignized by Allen is clothing. Mahfouz's Khan al-Khalili provides numerous references to the clothes worn by Egyptian people from different social classes and groups. For instance, the Arabic text in Example 7 describes how civil servants from the middle-class dress for work. They mainly wear pants, shirts with a necktie, and a jacket. The Arabic excerpt adds another clothing item: the طربوش (fez). The طريوش is a red cylindrical-hat Arab man used to wear for formal dress. In another excerpt, Example 8, Mahfouz describes what people usually wear in the house after they finish work. This includes a جلباب (a traditional Egyptian wide, long garment) and طاقيه (skullcap). Example 9 also provides an image of how religious men dress up in Egypt by wearing a جبب (a gownlike garment similar to a soutane) and a turban.

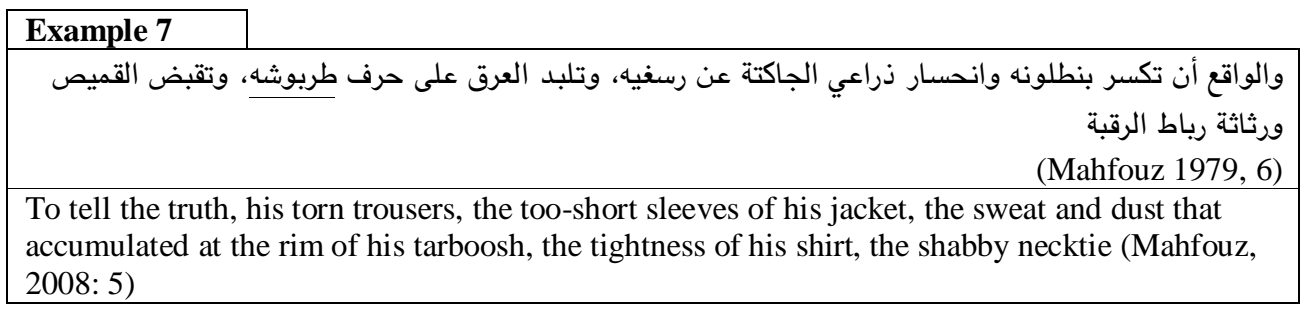

\begin{tabular}{|l|l|}
\hline Example 8 & فأغلق النافذتين وخلع بذلته، ثم ارتدى جلبابه وطاقيته \\
\cline { 2 - 4 } & (Mahfouz 1979, 12) \\
\hline $\begin{array}{l}\text { He shut the two windows, changed out of his business clothes, and put on a gallabiya and } \\
\text { skullcap. (Mahfouz 2008,9) }\end{array}$ \\
\hline
\end{tabular}

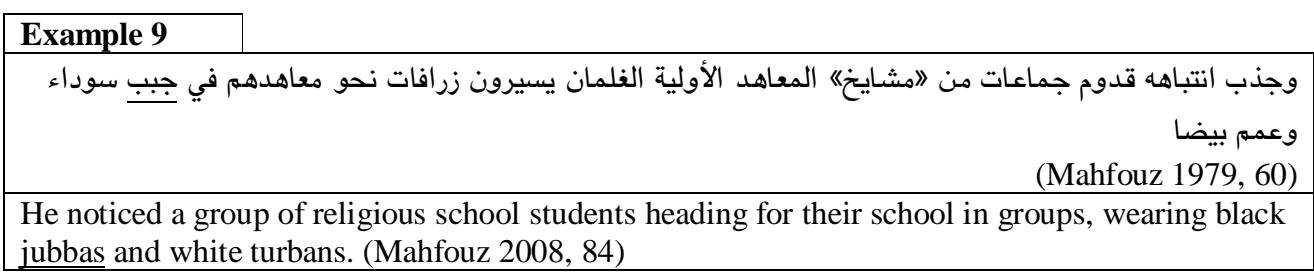

To maintain the cultural distinctiveness of the source text and to introduce the reader to traditional Egyptian attire, Allen opts to borrow Egyptian clothing terms into English. The borrowed clothing items, tarboosh (fez), gallabiyah ${ }^{2}$, and jubbas, complete Allen's successful project of producing a foreignized version of Mahfouz's text and successfully introduce another foreignized set of cultural elements to the target reader. 


\subsubsection{Rendering Religious Expressions}

Religious and Islamic terms included in Mahfouz's novel have been kept foreign by Allen, either by rendering them literally or by borrowing the religious phrase. For instance, Allen has borrowed the Arabic religious term متشهدين as "intoning the shahada" (Islamic creed), a culture/religion-specific expression chanted by Muslims as a sigh of relief (see Example 10). Allen uses both literalness and foreignness when translating the Arabic-Islamic expression يا نتاح يا عليم' into “O God, Opener, All-Knowing” in Example 11. This expression is used by Muslims to supplicate Allah by his different names (God, Opener, and AllKnowing) to make his/her day a good one. Similarly, in Example 12, the underlined part in Arabic " سبحان is rendered literally by Allen as "Praise be to the One who changes things but who never changes Himself."

\begin{tabular}{|c|c|}
\hline Example 10 & \\
\hline & ومضت فترة وجيزة في سكون ثم انطفت صفارات الأمان، فنهض القوم متشهدين(Mahfouz 1979, 99)_ \\
\hline
\end{tabular}

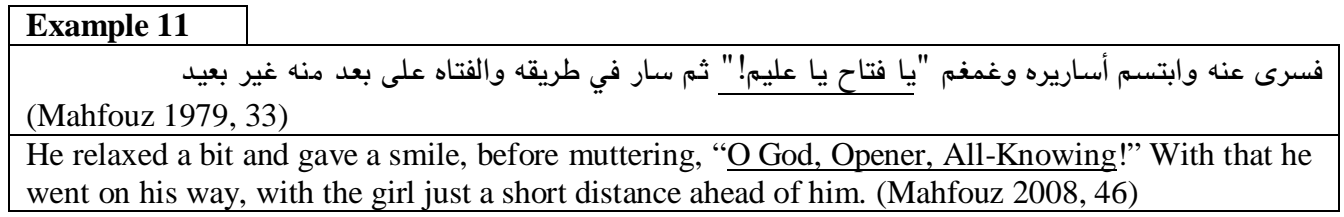

\begin{tabular}{|l|}
\hline Example 12 \\
\hline (Mahfouz 1979, 5) \\
\hline $\begin{array}{l}\text { Well might Ahmad Akif quote the phrase, "Praise be to the One who changes things but who never } \\
\text { changes Himself!"” (Mahfouz 2008, 4) }\end{array}$ \\
\hline
\end{tabular}

By doing so, Allen immerses the target text reader in a distinctly foreign experience and introduces him/her to a set of Arabic and Islamic expressions in context. Thanks to the borrowing and literal translation strategies, Allen's version of Mahfouz's novel fulfills the promise of the translation project in producing a foreignized version of Mahfouz.

\subsubsection{Rendering Arabic Characters' Titles}

Allen continues his translation with another set of foreignized expressions related to the honorifics used for the novel's characters. This foreignization act involved borrowing the Arabic words ست (Mrs.), هانم (Madame) (Example 14) and rendering them as Sitt ${ }^{3}$, Effendi $^{4}$, and Hanem $^{5}$. 
Translator-oriented Translation Criticism: The Case of Roger Allen's

Translation of Khan al-Khalili

\begin{tabular}{|c|c|}
\hline Example 13 & \\
\hline كأمك أيام & شبابها - صديقة قديمة مادفت اليوم فهو أن الست توحيدة حرم كمال أفندي خليل-وهي جسيمة كالمحمل \\
\hline $\begin{array}{l}\text { Something ev } \\
\text { Effendi-who } \\
\text { mine! (Mahfo }\end{array}$ & $\begin{array}{l}\text { more odd happened today. I met Sitt Tawhida, the wife of Kamal Khalil } \\
\text { as broad as your own mother when she was younger- she's an old friend of } \\
2008,86 \text { ) }\end{array}$ \\
\hline
\end{tabular}

Example 14

(Mahfouz 1979, 64)

قالت الست توحيده هانم انها كريمة يوسف بهلة العطار

Tawhida Hanem told me that it's the daughter of Yusuf Bahia, the perfumer! (Mahfouz 2008, 89)

When rendering the above examples into English, Allen could have used two different translation options. The first one is to translate the titles with their English equivalents to create a fluent English translation and to eliminate any foreignness that borrowing may cause. The second option is to borrow the Arabic titles into English and create a foreign translation. Allen's translation in the above example aligns with his project by borrowing the Arabic terms used in the source text.

\subsubsection{Rendering Culture-based Conversations}

Culture-based conversations are another central element in Mahfouz's novel. Many conversations in the novel provide important cultural, religious, and social contexts and references. As mentioned earlier, Mahfouz's style relies heavily on conversations between characters to provide the reader with a realistic image of Egyptian society. The conversation in Example 15 contains several social, religious, and cultural references that make the task of the translator harder:

\begin{tabular}{|c|c|}
\hline Exa & \\
\hline $\begin{array}{l}\text { That phrase "wives of Nunu" attracted Ahmad's } \\
\text { attention. He wondered exactly how many wives } \\
\text { Nunu had in his harem. ... The only way he could see } \\
\text { to find out was to ask a trick question: } \\
\text { "God is always there to help us. } \\
\text { You obviously have a large family." } \\
\text { "Eleven stars," the man replied simply, "and four } \\
\text { suns. Oh, and a single moon!" he went on, pointing to } \\
\text { himself. } \\
\text { "You have four wives?" Ahmad asked after a pause. } \\
\text { "As God wills." } \\
\text { "Aren't you afraid of not being fair to them all?" } \\
\text { "And who's to say that I'm unfair?" } \\
\text { "Do you rent four separate houses for them?" } \\
\text { "No, like you, sir, I've just one apartment. It has four } \\
\text { rooms, and there's a mother and her children in each } \\
\text { one." } \\
\text {.. } \\
\text { At this point Ahmad discovered a sense of daring that } \\
\text { was unusual for him. "Why haven't you been } \\
\text { satisfied with just one?" he asked. }\end{array}$ & 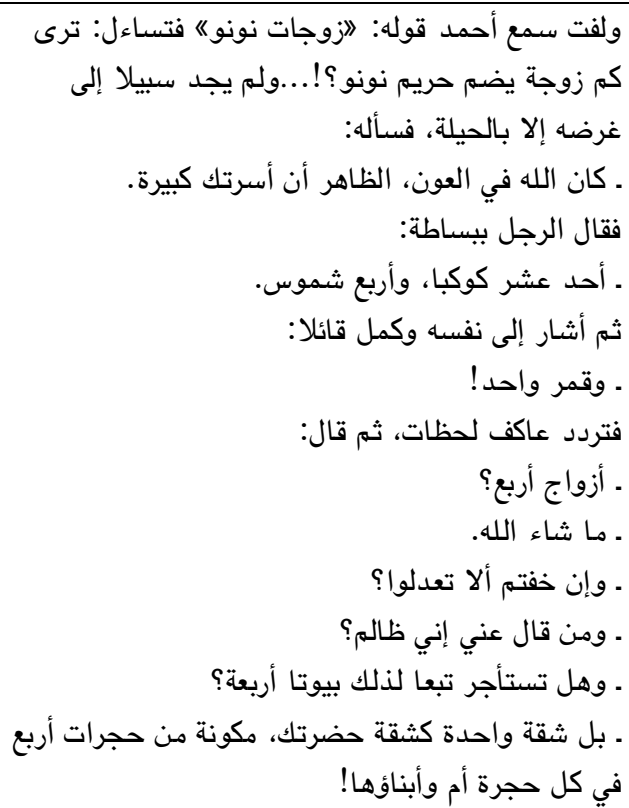 \\
\hline
\end{tabular}


"One?" came the reply. "I'm a calligrapher. Women are just like calligraphy; no single one can make up for the others. One's naskh, another ruq'a, another thuluth, and a fourth farsi. The only thing I have one of is God Almighty."

(Mahfouz 2008, 63)

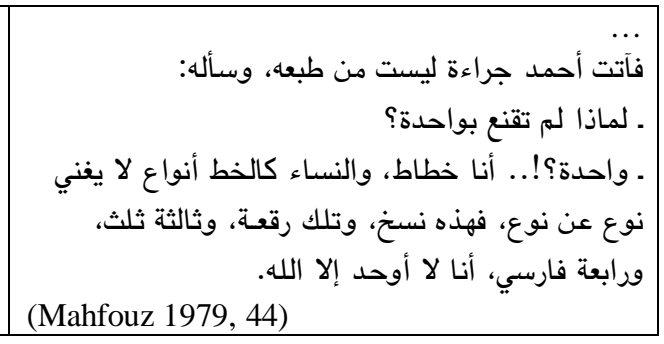

Allen has creatively translated the conversation by keeping the foreignness of the source and delivering the cultural messages embedded in the Arabic text. The excerpt discusses a controversial practice in Arab societies: polygamy. One of the characters, Ahmed, is against polygamy and the other character, Nunu, has four wives. Ahmed's curiosity pushed him to ask Nunu questions regarding his family: 'الظاهر أن أسرتك كبيرة.' (You obviously have a large family). Nunu replies that he has ، أحد عشر 'كوكبا، وأربع شموس. ثم أشار إلى نفسه وكمل قائلا: وقمر واحد (Eleven stars...four suns. ..., and a single moon! ... pointing to himself). Nunu's answer reflects three social constructs that were common in Egyptian society: (1) Egyptian household as patriarchal; (2) polygamy as a societal concept; and (3) the presence of big families in Egyptian society.

Allen's translation reflects the Arabic source text as it not only conveys the meaning embedded in the conversation but also reflects the tone and the attitude of the characters. Allen, as can be noticed from this simple comparison between the Arabic and English versions, mirrors the source text by employing the same images Nunu used in the Arabic version to talk about his wives.

The conversation continues with a question from Ahmed: "وإن خفتم ألا تعدلوا (If you fear that you may not be fair). The question is derived from a Quranic verse that says:

If you fear that you may not deal justly with the orphans, then marry [other] women that you like, two, three, or four. But if you fear that you may not treat them fairly, then [marry only] one, or [marry from among] your slave-women. (Qur'an 4: 3)

The Arabic reader can easily spot the link between Ahmed's questions and the Quranic verses that set the rules for having more than one wife. The English reader might not be able to understand the connection between Ahmed's question and the verse. To compensate, Allen explicitly translates Ahmed's question as "Aren't you afraid of not being fair to them all?" The conversation goes on; Ahmed asks, "ماذا لم تقنع بواحدة؟" (Why haven’t you been satisfied with just one?). Nunu answers:

\begin{tabular}{|c|c|}
\hline Example 16 & \\
\hline (Mahfouz 197 & ـ فارسي، أنا لا أوحدة !.. أنا خطاط، والنساء كالخط أنواع لا يغني نوع عن نوع، فهذه نسخ، وتلك رقعة، \\
\hline $\begin{array}{l}\text { "One?" came } \\
\text { make up for th } \\
\text { thing I have of }\end{array}$ & $\begin{array}{l}\text { reply. "I'm a calligrapher. Women are just like calligraphy; no single one can } \\
\text { thers. One's naskh, another ruq'a, another thuluth, and a fourth farsi. The only } \\
\text { of is God Almighty." (Mahfouz 2008, 64) }\end{array}$ \\
\hline
\end{tabular}


The translation of Nunu's answer was rendered brilliantly as it reflects Nunu's attitude towards having more than one wife while also introducing the English reader, again, to specific practices in Arab culture. In the last part of the conversation, Nunu describes women as Arabic calligraphy or fonts: نسخ، (Naskh, Ruq'a, Thuluth, Farsi). Allen borrowed Arabic fonts in his English translation to add more foreign flavor to the conversation and ultimately keeps his translation project's promise to maintain the foreignness of the Arabic text.

The Arabic text continues with more references from Arab-Islamic culture. The last sentence in Nunu's answer, 'أنا لا أوحد إلا الله' (The only thing I have one of is God Almighty), emphasizes Islamic belief that Allah is the one and only God. Allen keeps his consistent approach to rendering such Islamic expressions and literally translating them into English.

\section{Conclusion}

Using Berman's (1995) approach, the present paper has critically analyzed the translation of Mahfouz's Khan al-Khalili in light of Allen's translation project. It was clear from the analysis that the realization of Allen's translation project was successful in his final translation. Allen reproduced the tone of the Egyptian writer Mahfouz, whose voice is still heard in the translation. The English version of Khan al-Khalili was not "fluent" nor "transparent" (Venuti 1995); rather, the translator was "visible" (Venuti 1995), and the text was written in the "language of translation", a language that native English writers would not use in their original works. By producing this type of language in English, Allen emphasizes the foreignness of the text, leaves Mahfouz and his text in peace, and moves the reader closer to the Arab culture (Schleiermacher 2012).

An area for further research would be to apply Berman's model of translation criticism to the study of more than one work by Allen. It would also be promising to research a text translated by more than one translator to see how the translating position, horizon, and project of different translators could play a role in shaping the production of the translation. 


\section{دراسات المترجمين ونقد الترجمة الأدبية: دراسة حالة لترجمة \\ روجر ألن لرواية (خان الخليلي) \\ محمد بطاينة، رقية الصمادي \\ قسم الترجمة، جامعة اليرموك، الأردن المن \\ الملخص}

تتمحور هذه الدراسة حول المترجم عنصراً مهماً في عملية تقييم جودة الترجمة، وتقوم بتطبيق منهج برمان (1990)

لنقد الترجمة الأدبية، على ترجمة روجر ألن لرواية (خان الخليلي) لنجيب محفوظ من العربية إلى الإنجليزية. تهدف هذه الدراسة إلى الكثف عن مدى نجاح المترجم في ترجمة الجوانب الثقافية، والأسلوبية، واللفوية لرواية نجيب محفوظ إلى الإنجليزية، في ضوء أفق المترجم ومشروعه الترجمي، وعن طريق دراسة المترجم وتحليل خلفيته اللغوية، والثقافية، والأكاديمية. شملت بيانات هذه الدراسة مجموعتين من البيانات حيث تضمنت المجموعة الأولى نصوصاً حول حياة روجر ألن، وله وتطوره- مترجماً وأكاديمياً- وعلى النصوص التي كتبها بصفته مترجماً وباحث في الترجمة، والتي عبر فيها عن نظرته وموقفه من الترجمة، وتضمنت المجموعة الثانية النص الأصلي والترجمة الإنجليزية، لرواية (خان الخليلي). وقد خلصت هذه الدراسة بعد تحليل الييانات إلى أن روجر ألن نجح في نقل المحتوى، وأسلوب العمل الأصلي، إلى اللغة الإنجليزية، كما كثفت الدراسة عن أن حياة ألن وانغماسه في العالم العربي، وفي الثقافة العربية قد أثر بشكل إيجابي في ترجمته. وبالإضافة إلى ذلك، كثفت الدراسة عن أن تطييق منهج (برمان) لنقد الترجمة، يمكن أن يزودنا بمعلومات إضافية لا يمكن التوصل إليها عن طريق تحليل النص المترجهم فقط، مثل البحث في حياة المترجم، وتحليل فلسفته بصفته مترجماً، ونقل للنصوص الثقافية التي قد تلعب دوراً 
Translator-oriented Translation Criticism: The Case of Roger Allen's

Translation of Khan al-Khalili

\section{Endnotes}

${ }^{1}$ Ful mudammis is a dish made of beans, probably the most characteristic breakfast dish in Egypt.

${ }^{2}$ Gallabiyah or jellabiya is a traditional Egyptian garment resembling a thobe but with a wider cut, no collar (and sometimes no buttons), and longer, wider sleeves.

${ }^{3}$ Sitt is the commonly used word for female head of household. It means "woman" but implies something close to the English "Mrs.".

${ }^{4}$ Effendi is close to the English "Mr.". It also means the father of the household.

${ }^{5}$ Hanem is a Turkish word for a woman, but in Egyptian terms means a woman of breeding and stature, an honorific title. The use of "Madame" in English parlance conveys something of the same effect.

\section{References}

Al-Amayreh, Zein. 2019. "Strategies of the Literary Translation in Two Different Arabic Translations of Hamlet:, A Comparative Study." Dirasat, Human and Social Sciences 46 (1): 287. https://doi.org/10.35516/0103-046-986-018.

Al-Qinai, Jamal. 2000. "Translation Quality Assessment. Strategies , Parametres and Procedures." Meta: Translators' Journal 3 (45): 497-519. https://doi.org/10.7202/001878ar.

Alkhawaja, Linda. 2014. "Interview with Roger Allen." in The Role of Social Agents in the Translation into English of the Novels of Naguib Mahfouz. PhD Diss., Aston University.

Allen, Roger. 1988. "Arabic Literature and the Nobel Prize." World Literature Today 62 (2): 201. https://doi.org/10.2307/40143526.

Allen, Roger. 1992. A Period of Time. 2nd ed. New York: Ithaca.

Allen, Roger. 1995. The Arabic Novel: An Historical and Critical Introduction. New York: Syracuse University Press.

Allen, Roger. 2000. An Introduction to Arabic Literature. 1st ed. Cambridge: Cambridge University Preåss.

Allen, Roger. 2003. "Translating Arabic Literature." Translation Review 65 (1): 1-5. https://doi.org/10.1080/07374836.2003.10523830.

Allen, Roger. 2004. "Roger Allen - Penn Arts and Sciences.” Roger Allen Personal Web Page. 2004. https://www.sas.upenn.edu/ rallen/.

Allen, Roger. 2007. "Rewriting Literary History: The Case of the Arabic Novel." Journal of Arabic Literature. https://doi.org/10.1163/157006408X292916.

Allen, Roger. 2008. "Introduction.” In Khan Al-Khalili, translated by Roger Allen, 312. Cairo: The American University in Cairo Press.

Allen, Roger. 2009. "'Fiction and Publics: The Emergence of the 'Arabic Best-Seller." The Middle East Institute Viewpoints: The State of the Arts in the Middle East 1: 9-12. https://www.mei.edu.

Allen, Roger. 2010. “The Happy Traitor: Tales of Translation.” Comparative Literature Studies 47 (4): 
472-86.

Allen, Roger. 2011. "Rewriting Literary History: The Case of Moroccan Fiction in Arabic." Journal of North African Studies. https://doi.org/10.1080/13629387.2010.550725.

Allen, Roger. 2015. “Translating Arabic Fiction.” Journal of Arabic Literature 46: 157-67.

Allen, Roger, and Adel Allouche. 1986. Let's Learn Arabic: A Proficiency-Based Syllabus for Modern Standard Arabic. Pennsylvania: University of Pennsylvania.

Almanna, Ali. 2016. The Routledge Course in Translation Annotation: Arabic-English-Arabic. London \& New York: Routledge. https://doi.org/10.4324/9781315665580.

Almutairi, Mashael. 2018. "The Objectivity of the Two Main Academic Approaches to TQA: An Analytical Study.” SKASE Journal of Translation and Interpretation 11: 79-95.

Alwafai, Salwa. 2015. "Some Aspects of Equivalence in Literary Translation: Analysis of Two Arabic Translations of Ernest Hemingway's The Old Man and the Sea 1952.” Arab World English Journal (AWEJ) 6: 320-35.

American University of Beirut. 2017. “Arabic and Translation: Lecture by Dr. Roger Allen.” 2017. https://www.youtube.com/watch?v=GFo_Ss2eRSw.

ArabLit. 2015. "Pioneer Translator Roger Allen on a Text He's Been Working with for the Last 50 Years." Arab Lit, September 14 https://arablit.org/2015/09/14/pioneer-translator-roger-allen-on-atext-hes-been-working-with-for-the-last-50-years/.

Baker, Mona. 1992. In Other Words: A Coursebook on Translation. London: Routledge.

Behtash, Esmail, and Masoumeh Moghadam. 2017. "Translation Evaluation: A Comparative Study of an Oblique Translation.” International Journal of Language \& Translation Studies 5 (2): 108-12.

Berman, Antoine. 1995. Toward Translation Criticism: John Donne. Translated by Francoise Massardier-Kenney. Kent: Kent State University Press.

Catford, John. 1965. A Linguistic Theory of Translation. London: Oxford Univ Press.

Chesterman, Andrew. 2009. "The Name and Nature of Translator Studies." HERMES - Journal of Language and Communication in Business, 42: 13-22. https://doi.org/10.7146/hjlcb.v22i42.96844.

El-Zawawy, Amr M. 2019. “The Description of the Setting in Two Translations of Naguib Mahfouz's Midaq Alley." FORUM. Revue Internationale d'interprétation et de Traduction / International Journal of Interpretation and Translation 17 (2): 149-91. https://doi.org/10.1075/ forum.19002.zaw.

Genette, Gerard. 1997. Paratexts: Thresholds of Interpretation. Cambridge University Press. https://doi.org/http://dx.doi.org/10.1017/CBO9780511549373.

Halim, Hala. 2006. "Between Words: Living Language." Al-Ahram, 2006. http://weekly.ahram.org.eg/Archive/2006/788/cu4.htm.

Himmich, Bensalem. 2009a. The Polymath. Translated by Roger Allen. Cairo: The American University in Cairo Press.

immich, Bensalem. 2009b. The Theocrat. Translated by Roger Allen. Cairo: The American University in Cairo Press. 
Holmes, James. 1979. “The Name and Nature of Translation Studies.” In Translated! Papers in Literary Translation and Translation Studies, edited by James Holmes, 66-80. Amsterdam: Rodopi. https://doi.org/10.1063/1.4813489.

Idris, Yusuf. 1978. In the Eye of the Beholder. Translated by Roger Allen. New York: Bibliotheca Islamica.

Jabra, Jabra. 1985. The Ship. Translated by Adnan Haydar and Roger Allen. Washington, D.C.: Three Continents Press.

Jabra, Jabra. 2000. In Search of Walid Masoud. Translated by Roger Allen and Adnan Haydar. Syracuse: Syracuse University Press.

Mahfouz, Naguib. 1973. God's World: An Anthology of Short Stories. Translated by Akef Abadir and Roger Allen. Minneapolis: Bibliotheca Islamica.

Mahfouz, Naguib. 1979. Khan al-Khalili. Misr lilteba'a: Cairo.

Mahfouz, Naguib. 2008. Khan Al-Khalili. Translated by Roger Allen. 1st ed. Cairo: The American University in Cairo Press.

Massardier-Kennedy, Françoise. 2009. “Translator's Introduction.” In Toward a Translation Criticism: John Donne by Antoine Berman, edited by Françoise Massardier-Kennedy, vii-xvii. Kent: Kent State University Press.

Moghadas, Seyed Mohammad. 2014. "Translation Criticism and Berman's Translation Project." International Journal of English and Education 3 (4): 374-86.

Munif, Abd Al-Rahman. 2007. Endings. Translated by Roger Allen. Northampton: Interlink.

Nida, Eugene. 1964. Toward a Science of Translating: With Special Reference to Principles and Procedures Involved in Bible Translating. Leiden: E. J. Brill.

Nord, Christiane. 1997. “A Functional Typology of Translation.” In Text Typology and Translation Language, edited by Anna Trosborg, 43-66. Philadelphia: John Benjamins Publishing.

Reiss, Katharina. 1976. Translation Criticism- Potentials and Limitations: Categories and Criteria for Translation Quality Assessment. London: Routledge.

Reiss, Katharina, and Hans Vermeer. 1989. Towards a General Theory of Translational Action. London: Routledge.

Robinson, Douglas. 1991. The Translator's Turn. 1st ed. Baltimore: Johns Hopkins University Press.

Sayaheen, Mohannad, Tengku Mahadi, and Bilal Sayaheen. 2019. "Foreignizing. or Domesticating English Children's Literature Translated into Arabic: The Case of Alice's. Adventures in Wonderland." International Journal of Humanities, Philosophy and Language 2 (8): 175-87. https://doi.org/10.35631/ijhpl.280013.

Schleiermacher, Friedrich. 2012. "On the Different Methods of Translating." In The Translation Studies Reader, edited by Lawrence Venuti, translated by Susan Bernofsky, 43-63. New York: Routledge.

Telmissany, Mayy. 2000. Dunyazad. Translated by Roger Allen. London: Saqi Books.

Venuti, Lawrence. 1995. The Translator's Invisibility: A History of Translation. Criticism. Vol. 28. 
London and New York: Routledge. https://doi.org/10.4324/9780203360064.

Vermeer, Hans. 2000. "Skopos and Commission in Translational Action." In The Translation Studies Reader, edited by Lawrence Venuti, 221-33. London and New York: Routledge.

Vinay, Jean-Paul, and Jean Darbelnet. 1995. Comparative Stylistics of French and English: A Methodology for Translation. Translated by Juan Sager and M Hamel. 1st ed. Amsterdam: John Benjamins Publishing.

World Who's Who. 2018. "Dr. Roger Michael Ashley Allen.” 2018. http://www.worldwhoswho. com/public/views/entry.html?id=s12174388. 